\title{
KINERJA PEMERINTAH DESA DALAM MENERAPKAN APLIKASI SISTEM KEUANGAN DESA (SISKEUDES) DI KECAMATAN KULISUSU KABUPATEN BUTON UTARA
}

\section{THE PERFORMANCE OF THE VILLAGE GOVERNMENT IN IMPLEMENTING THE VILLAGE FINANCIAL SYSTEM APPLICATIONS (SISKEUDES) IN KECAMATAN KULISUSU, BUTON UTARA DISTRICT}

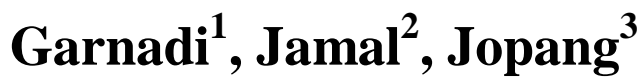 \\ 1) Alumni Program Studi Administrasi Publik Pascasarjana UHO Kendari; e-mail \\ nadimakayclasmail@gmail.com \\ 2) Dosen Program Studi Administrasi Publik Pascasarjana UHO Kendari; e-mail \\ Elsikapi2002@gmail.com \\ 3) Dosen Program Studi Administrasi Publik Pascasarjana UHO Kendari; e-mail \\ jopangopang@uho.ac.id
}

\begin{abstract}
ABSTRAK
Penelitian ini bertujuan mendeskripsikan kinerja pemerintah desa dalam menerapkan aplikasi sistem keuangan desa (Siskeudes) di kecamatan kulisusu Kabupaten Buton Utara. Penelitian ini dilakukan dengan cara purposive sampling, dengan model analisis data interaktif. Metode yang digunakan adalah Pendekatan kualitatif dengan teknik Pengumpulan data menggunakan teknik observasi, wawancara dan studi dokumen, kemudian dianalisis secara deskriptif. Hasil penelitian ini menunjukan bahwa kinerja pemerintah desa dalam mengoptimalkan penerapan aplikasi sistem keuangan desa (Siskeudes) dalam menilai kinerja organisasi dapat berfungsi secara optimal, tergambar melalui tampilan output berupa data dan informasi yang cepat dan akurat sesuai harapan, kemampuan beradaptasi dan penyesuaian informasi setiap ada perubahan data input serta keberlanjutan dalam penyajian data informasi keuangan desa. dapat dilihat dalam dimensi sistem kerja organisasi yaitu Sumber daya Manusisa yang Kompeten dalam mendukung penerapan Aplikasi Sistem Keuangan yang dilihat melalui input memadai, proses yang baik, sehingga menghasilkan output maksimal.

Kata kunci: Aplikasi sistem informasi keuangan, Kinerja organisasi, Pemerintah desa
\end{abstract}

\begin{abstract}
This study aims to describe the performance of the village government in implementing the village financial system application (Siskeudes) in Kulisusu sub-district, North Buton Regency. This research was conducted by means of purposive sampling, with an interactive data analysis model. The method used is a qualitative approach with data collection techniques using observation techniques, interviews and document study, then analyzed descriptively. The results of this study indicate that the performance of the village government in optimizing the application of the village financial system (Siskeudes) in assessing organizational performance can function optimally, as illustrated by the output display in the form of data and information that is fast and accurate as expected, the ability to adapt and adjust information every time there is a change. input data and sustainability in presenting village financial information data. can be seen in the dimensions of the organizational work
\end{abstract}


system, namely Competent Human Resources in supporting the application of the Financial System Application seen through adequate input, good processes, resulting in maximum output.

Keywords: Financial information system applications, Organizational performance, Village government

\section{PENDAHULUAN}

Pemerintah desa memiliki hak otonomi untuk mengatur, mengurus, mengelola dan mengembangkan potensi yang dimilikinya. Pemberlakuan Undang Undang Desa yaitu UU No 6 Tahun 2014 tentang Desa, menguatkan posisi desa sebagai unit pelaksana pemerintahan yang paling dekat dengan masyarakat. Desa diberi ruang dan kesempatan untuk mengelola pemerintahan sendiri serta pelaksanaan pembangunan untuk meningkatkan kesejahteraan dan kualitas hidup masyarakat desa menggunakan potensi dan sumber penerimaan desa, sesuai dengan aturan yang berlaku. Dengan otonominya, pemerintah desa diharapkan lebih mandiri dalaam mengelola pemerintahan, melaksanakan pembangunan dan memberikan pelayanan kepada masyarakatnya. Karena itu, pada saat yang sama, pemerintah juga memiliki tanggung jawab yang berat untuk menjamin pelaksanaan pembangunan dan pelayanan publik, dengan menggunakan secara efektif dan efisien anggaran yang dilakokasikan kepada pemerintah desa.

Potensi perekonomian desa menjadi modal utama dalam mendorong percepatan kemajuan desa. Seiring dengan pelaksanaan UU desa, pemerintah desa mendapatkan alokasi dana desa dari APBN setiap tahunnya. Menurut Arsyad (2016), potensi ekonomi desa yang kuat dapat mempercepat kemajuan desa serta menjadi pendorong bagi tercapainya kesejahteraan rakyat.

Anggaran Pendapatan dan Belanja Desa (APBDesa) dibuat untuk memaksimalkan pengelolaan dana desa dan potensi penerimaan desa lainnya. Pengelolaan APB Desa harus dijalankan sesuai dengan mekanisme perencanaan yang memenuhi prosedur perencanaan ideal, dilaksanakan sesai dengan aturan sehingga memberikan manfaat dan dampak yang maksimal bagi kemajuan desa. Menurut Eko (2014), setiap upaya yang dilakukan pemerintah desa dalam pengelolaan anggaran dan belanja desa mengarah pada terciptanya pengelelolaan keuangan desa yang efektif dan efisisen serta tidak menyalahi kaidah atau aturan pengelolaan keuangan desa.

Di Buton Utara, pemeritah kabupaten sudah mulai menerapkannya sejak tahun 2016 dan saat ini, sistem tata kelola keuangan desa telah diimplementasikan secara nasional. Tahapan penerapan sistem tatakelola keuangan desa secara nasional menurut BPKP (2018) dilakukan mulai dari penyiapan modul sebagai pedoman Siskeudes, sosialisasi program, penerapan aplikasi sistem keuangan desa, penyediaan program dalam bentuk softwear, penyedian peralan berupa computer dan akses jaringan secara online, penyediaan fitur dan WEB online, panduan pengisian form dalam WEB serta penyediaan pendampingan dan bimbingan teknis penerapan aplikasi sistem tata kelola keuangan desa. Penerapan aplikasi sistem keuangan desa dimaksudkan agar dalam perencanaan, pelaksanaan, pelaporan dan pertanggungjawaban keuangan desa diakukan secara akuntabel dan transparan serta mengikuti aturan.

Secara kelembagaan, institusi yang diberikan kewenangan melakukan pembinaan dan pengawasan terhadap peneyelanggaraan pemerintahan desa termasuk berkaitan dengan pengelolaan anggaran adalah Dinas Pemberdayaan Masyarakat dan Desa (DPMD). Di Kabupaten Buton Utara, Dinas Pemberdayaan Masyarakat dan Desa merupakan unsur pelaksana Pemerintah Daerah di Bidang Pemberdayaan Masyarakat dan Pemerintahan Desa, dibentuk berdasarkan Peraturan Daerah Nomor 6 Tahun 2016 tentang Pembentukan dan Susunan Perangkat Daerah Kabupaten Buton Utara. OPD ini memiliki tugas pokok, fungsi dan tatakerja sebagaimana yang diatur dalam Peraturan Bupati Buton Utara Nomor 35 Tahun 2016 tentang Kedudukan, Susunan Organisasi, Tugas dan Fungsi serta Tata Kerja Dinas 
Pemberdayaan Masyarakat dan Desa Kabupaten Buton Utara. Esensi pemberdayaan masyarakat pada dasarnya mengembangkan kemampuan, kemandirian dan peran aktif masyarakat dalam pembangunan, agar secara bertahap masyarakat dapat membangun diri dan lingkungannya secara mandiri dengan menciptakan demokratisasi, transparansi dan akuntabilitas dalam pengelolaan pembangunan pada tingkat masyarakat. Demokratisasi dan transparansi dalam pembangunan dilakukan melalui pemberian wewenang secara proforsional kepada masyarakat untuk mengambil keputusan secara mandiri tentang program program pembangunan yangakan dilaksanakan sesuai dengan kebutuhan dan prioritas permasalahan yang dihadapi oleh masyarakat. Dengan demikian pemerintah daerah berperan sebagai fasilitator melalui pemberian bantuan, pembinaan, bimbingan, arahan, evaluasi dan monitoring pelaksanaan (LAKIP DPMD, 2018).

Pembinaan pengelolaan keuangan desa berada dikordinasi langsung Bidang Pemerintahan Desa. Bidang Pemerintahan Desa dipimpin oleh seorang Kepala Bidang yang berada dibawah dan bertanggungjawab kepada Kepala Dinas dan mempunyai tugas melaksanakan penyelenggaraan pemberdayaan masyarakat dan Pemerintahan Desa serta pembangunan desa dan kawasan pedesaan.

Untuk mendukung transparansi dan akuntabilitas pengelolaan dana desa, pemerintah dalam hal ini BPKP mengembangkan sistem informasi desa dan sistem informasi keuangan desa. Pengembangan sistem informasi desa dimaksudkan untuk menjamin agar setiap kebijakan pemerintah desa diketahui oleh masyarakat. Dalam Kasus Buton Utara, upaya mewujudkan transparansi dan akuntabilitas pemerintahan desa, telah diterapkan sistem informasi pemerintah desa dan sistem informasi keuangan desa. Olehnya itu perlu dilakukan penelitian tentang kinerja pemerintah desa dalam mengaplikasikan sistem keuangan di Kecamatan Kulisusu Kabupaten Buton Utara.

\section{TINJAUAN PUSTAKA \\ Konsep Ukuran Kinerja Organisasi}

Pengukuran kinerja organisasi menurut Siagian (2009) mencakup sejumlah kriteria yang digunakan yaitu: a) Kriteria kejelasan tujuan yang hendak dicapai, hal ini dimaksudkan agar pelaksana lebih terarah dalam mencapai tujuan dan sasaran yang telah ditetapkan oleh organisasi; b) Kriteria kejelasan strategi untuk mencapai tujuan, yakni ada pendekatan atau cara yang tepat harus dilakukan untuk mencapai sasaran-sasaran yang ditentukan sehingga para pelaksana berjalan pada rel yang benar dalam pencapaian tujuan organisasi. Kinerja yang baik tergambar dari sejauhmana tindakan yang dilakukan konsisten dengan strategi pendekatan yang dibuat; c) Proses analisis dalam perumusan program atau kebijakan yang ditetapkan dilakukan secara tepat sehubungan dengan tujuan yang hendak dicapai. Artinya, kinerja yang baik terlihat dari sejauhmana kebijakan atau program yang dibuat mampu menjembatani tujuan-tujuan dengan usaha-usaha yang dilaksanakan; d) Perencanaan yang tepat, yakni kinerja dikatakan baik, jika pengambilan keputusan oleh pimpinan mampu mempertimbangkan seluruh aspek pengganggu sehingga memudahkan dalam implementasi; e) Kriteria penyusunan program yang tepatartinya kinerja yang baik jika mampu menyusun program agar pelaksanaannya lebih fokus dalam bekerja untuk mencapai sasaran yang ditetapkan; f) Kriteria penyediaan sarana dan prasarana kerja yang menunjang pelaksanaan kegiatan untuk mencapai tujuan dan sasaran yang jelas, kinerja dikatakan baik jika organisasi mampu menyediakan sarana dan prasarana yang mendukung pelaksanaan pekerjaan; g) Pelaksanaan yang efektif dan efisien artinya kinerja dikatan baik jika setiap orang atau kelompok dalam organisasi mampu menjalankan aktivitas dan kegiatannya diatas rel yang benar, sehingga memudahkan dalam merealisasikan tujuan dan sasaran secara tepat; h) Kriteria sistem pengawasan dan pengendalian dimana kinerja dikatakan baik jika sistem pengawasan dan pengendalian bersifat mengarahkan dan memberikan petunjuk sehingga target-target yang ditetapkan dapat direalisasikan secara tepat sesuai jumlah yang ditentukan, kualitas sesuai standard dan diwujudkan dalam waktu yang tepat. 
Tangkilisan (2009) mengemukakan kriteria kinerja organisasi dicirikan oleh sejumlah indikator yaitu: a) kinerja baik jika capaian hasil sesuai dengan yang direncanakan; b) kemampuan beradaptasi, dimana kinerja dikatakan baik jika organisasi mampu beradaptasi dengan lingkungan yang terus berubah; c) tingkat kepuasan kerja, dikatakan kinerja organisasi baik jika organisasi mampu memberikan kepuasan kerja bagi para pelaksana; d) kemampuan berlaba atau memperoleh keuntungan atau manfaat dan pencarian sumber daya yang jelas, dikatakan kinerja baik jika organisasi mampu menghasilkan keuntungan sebesarbesarnya dengan sumber daya yang tersedia. Kinerja organisasi tergambar dari bukan hanya dilihat dari pencapaian hasil melainkan pada tingkat sejauhmana suatu organisasi melaksanakan kegiatan dan memberdayakan setiap elemen, mampu memberikan kepuasan kerja serta mampu menghasilkan keuntungan yang besar dalam kondisi lingkungan organisasi yang terus berubah. Kriteria ini sesuai dengan Steers (2015) yang mengemukakan lima kriteria dalam pengukuran kinerja organisasi yaitu: a) Produktivitas; b) Kemampuan adaptasi atau fleksibilitas; c) Kepuasan kerja; d) Kemampuan berlaba; e) Pencarian sumber daya untuk memaksimal pencapaian hasil dalam organisasi.

Mangkunegara (2010) memberikan kriteria atau ukuran kinerja organisasi yang menyangkut faktor internal organisasi dan faktor eksternal organisasi yang meliputi antara lain: a) Produktivitas organisasi atau output; b) Kinerja organisasi dalam bentuk keberhasilannya menyesuaikan diri dari perubahan-perubahan didalam dan diluar organisasi; c) Tidak adanya ketegangan di dalam organisasi atau hambatan-hambatan konflik diantara bagian-bagian organisasi. Konsep tersebut diatas jelas meyangkut tiga elemen yang berbicara mengenai produktivitas organisasi sebagai output, kemampuan organisasi untuk menyesuaikan diri dengan perubahan lingkungan, dan bagaimana organisasi mengelola dan mengatasi konflik internal yang terjadi. Rancangan terhadap studi tentang kinerja organisasi meliputi ketiga konsep yang diajukan oleh Steers diatas dimana ketiganya saling berhubungan. Sifat hubungan dilihat antara elemen-elemen tersebut mempengaruhi untuk mempermudah atau menghambat pencapaian tujuan organisasi yang mungkin atau layak dicapai.

\section{Konsep Pengelolaan Keuangan Desa}

Mardiasmo (2014) mengatakan pemberian dana desa yang semakin meningkat dari tahun ketahun, memerlukan aparat yang mampu mengelola dan memberikan pelaporan yang beragam dalam setiap aspek dan tahapan pengelolaan anggaran. Perlunya pelaporan dalam setiap tahapan secara online untuk memastikan bahwa pengelolaan anggaran dapat diawasi secara bertahap untuk menghindari kekeliruan dalam alokasi, memberikan kepastian penggunaan anggaran baik jumlah maupun peruntukan yang sesuai dengan rencana. Hal itu perlu, karena adanya titik-titik kritis dalam pengelolaan keuangan desa yang memungkinkan dimanipulasi jika tidak diawasi secara ketat, terstruktur dan intensif melalui setiap tahapan dalam pelaksanaan anggaran desa.

Pelaporan dengan sistem aplikasi secara online menurut Mulyani (2016) menjadikan pemerintah desa berserta aparat pengelola anggaran desa mampu menerapkan prinsip-prinsip akuntabilitas dan transparansi pengelolaan keuangan desa sebagai bagian dan penyelenggaraan pemerintahan desa yang bertanggungjawab termasuk dalam pengelolaan dana desa untuk mewujudkan tata kelola pemerintahan desa yang baik (Good Village Governance). Anggaran yang memadai menurut Kartasasmita (2010) menjadikan desa lebih cepat maju, asalkan para pengelola memahami cara-cara menggunaakan anggara secara benar, tepat dan memenuhi kebutuhan pembangunan desa. Untuk menerapkan aplikasi sistem pengelolaan keuangan desa termasuk dalam pelaporan keuangan desa menurut Mulyani (2016) diperlukan berbagai sumber daya dan sarana pendukung, diantaranya sumber daya manusia yang kompeten serta dukungan sarana teknologi informasi yang memadai dan dapat diandalkan berupa jaringan online, komputer disertai softwear dan hardwear yang memenuhi 
standar untuk mendukung penyampaian informasi secara online, serta kebijakan yang menjadi pedoman kerja dan pengawasan dalam proses pengelolaan keuangan desa.

\section{METODE}

Penelitian ini menggunakan penelitian kualitatif dan berlokasi di desa Kecamatan Kulisusu Kabupaten Buton Utara. Informan dalam penelitian ini sebanyak 7 Orang dari Dinas Pemberdayaan Masyarakat dan Desa (DPMD) serta Desa yang ditetapkan secara purposive sampling adalah mereka yang memiliki pengetahuan tentang substansi yang diteliti. Pengumpulan data dilakukan melalui observasi, wawancara dan studi dokumen. Data yang telah dikumpulkan dianalisa secara deskriptip kualitatif.

\section{HASIL DAN PEMBAHASAN Kinerja Organisasi}

Keberhasilan organisasi mencapai targetnya kalau semua koponen pendukung baik internal maupun eksternal terpenuhi. Kenyataan tersebut menurut Indrawijaya (2010) menjadikan organisasi jarang sekali mencapai targetnya secara keseluruhan ketika komponen pendukungnya tidak tersedia. Menurut Jones (1994) dalam Mohammad, dkk. (2015) pencapaian kinerja organisasi ditentukan oleh faktor input (masukan), terpenuhi, conversion atau proses yang tepat, akan menghasilkan output atau hasil maksimal. Input meliputi semua sumber daya yang dimiliki, informasi dan pengetahuan, bahan-bahan mentah serta modal. Dalam hal input, efesiensi sumber daya yang digunakan menentukan hasil yang dicapai. Tahap conversion ditentukan oleh proses manajemen, yakni kemampuan organisasi memanfaatkan sumber daya dimiliki, termasuk penggunaan teknologi agar dapat memberikan nilai tambah. Pada tahap ini, tingkat keahlian SDM dan daya tanggap organisasi terhadap perubahan lingkungan sangat menentukan tingkat kinerja dan produktivitas. Pada aspek output, pelayanan yang diberikan personil dalam organisasi terkait dengan memanfaatan sumber daya secara efisien untuk dapat meningkatkan kualitas pelayanan guna memuaskan pelanggan.

Kinerja organisasi dalam penelitian ini diukur menggunakan pengukuran kinerja dari perspektif pendekatan sebagaimana dikemukakan Etzioni (2009), Katz dan Kahn (2009) dan Kasim (1993) memandang organisasi sebagai satu kesatuan dari berbagai unsur yang saling berhubungan secara fungsional dengan lingkungannya untuk mencapai tujuannya. Menurut Etzioni (2009) faham ini mencoba menilai kinerja organisasi dari segi sejauhmana unsur-unsur dalam organisasi dapat berfungsi secara optimal. Organisasi ditempatkan sebagai satu model sistem terbuka dimana keberhasilannya tergambar dari sejauhmana subsistem yang membentuknya bekerja secara baik, didukung input memadai, proses yang baik, sehingga menghasilkan output maksimal sebagaimana dikemukakan Katz dan Kahn (2009) dan Kasim (1995). Dalam sistem informasi keuangan, kinerja yang baik menurut Aprianijaya, dkk. (2012) tergambar melalui tampilan output berupa data dan informasi yang cepat dan akurat sesuai harapan, kemampuan beradaptasi dan penyesuaian informasi setiap ada perubahan data input serta keberlanjutan dalam penyajian data informasi keuangan desa. Untuk dapat bekerja dengan baik menurut Mulyani (2016); diperlukan sumber daya manusia yang kompeten, teknologi memadai, serta pengendalian internal berupa pembinaan, pengawasan dan pemeliharaan dalam mendukung capaian kinerja yang maksimal.

\section{Kinerja Organisasi Dalam Menerapkan Aplikasi Sistem Keuangan Desa di Kecamatan Kulisusu Kabupaten Buton Utara.}

Merujuk pada peraturan pemerintah dalam hal ini transparansi pengelolaan keuangan desa dikembangkan aplikasi sistem keuangan desa (Siskeudes) oleh Pengawasan Bidang Penyelenggaraan Keuangan Daerah BPKP di Jakarta (DJPK-Kemenkeu, 2015). Aplikasi ini menurut Santoso (2011) menciptakan efisiensi dan efektivitas pengelolaan keuangan desa, 
karena penggunaan anggaran menjadi terarah dan terkontrol, serta kinerja keuangan menurut Silalahi, dkk. (2015) semakin mudah dievaluasi karena target kinerja menjadi terukur. Aplikasi keuangan desa disyaratkan BPKP selaku pengembang aplikasi berbasis database dan memudahkan pengelola dan para pihak berkepentingan serta auditor memantau dilakukan dengan anggaran di desa. Menurut Suparman, dkk. (2014) mitra pemerintah daerah dalam mengembangkan aplikasi keuangan desa adalah BPKP. Karena itu mereka harus selalu berkordinasi dengan pimpinan BPKP di daerah masing-masing.

Pengukuran kinerja dalam menerapkan aplikasi sistem keuangan desa di desa, tergambar melalui dimensi antara lain;

1) Sejauhmana informasi yang disampaikan dalam sistem sesuai dengan informasi yang diperlukan untuk mengetahui pengelolaan keuangan desa mu;ai dari tahap penganggaraan, penatausahaan dan pelaporan;

2) Kesesuaiaan jenis laporan yaitu setiap informasi yang disampaikan atau yang diinput dalam sistem sesuai dengan tahapan altivitass dan kegiatan pengelolaan keuanagan atau APBDesa;

3) Ketepatan dan kepastian waktu pelaporan yaitu setiap periode waktu yang ditentukan dan setiap selesai melaksanakan kegiatan harus dilanjutkan dengan peingputan data pelaporan kegiatan secara tepat waktu;

4) Akurasi data yaitu data atau informasi yang terimput dalam sistem adalah data yang valid, terbaru dan data riil yang menjelaskan fakta sesungguhnya, buka data semu atau data fiktif yang berbeda dengan apa yang terjadi;

5) Kesesuaian, persyaratan dan prosedur, dan tahapan pelaporan, mulai dari penganggaran, penatausahaan dan pelaporan;

6) Penggunaan anggaran terferifikasi artinya apa yang dilaporkan dapat diferifikasi faktanya dalam bentuk dokumen atau kas anggaran yang ada;

7) Feedback pelaporan; yaitu ada tindaklanjut dari setiap periode pelaporan dan penyesuaian data dalam laporan manakala laporan yang disampaikan tidak relevan dengan apa yang dikehendaki oleh sistem laporan keuangan yang disediakan (BPKP, 2015)

Aplikasi sistem pengelolaan keuangan desa melalui komputerisasi berkembang seiring dengan berkembangnya teknologi dan telah menjadikan data yang tepat dan akurat. Menuntut Kepala desa Kadacua Kecamatan Kulisusu Kabupaten Buton Utara, penggunaan komputer dalam sistem keuangan desa menuntut adanya ketepatan informasi yang diperlukan sesuai program dan kebutuhan yang diperlukan setiap waktu. Untuk itu maka kebutuhan SDM yang kompeten dimana memiliki kemampuan untuk mengoprasikan sistem pengelolaan keuangan desa secara online mendesak harus dipenuhi. Di sini diperlukan keterampilan dan keahlian menggunakan aplikasi IT, karena setiap pekerjaan terkait dengan teknologi informasi dan komputerisasi. Salah satu tugas atau pekerjaan yang membutuhkan personil yang menguasai teknologi komputer dalam pengelolaan data dan informasi adalah bagian analisis dan input data. Berikut pernyataan Kasubag. Perencanaan DPMD/admin siskeudes Kabupaten Buton Utara bahwa:

"Penyediaan data dan informasi sistem keuangan desa memerlukan SDM yang mampu mengoperasionalkan teknologi komputer, menganalisis data, menyajikan data dan informasi yang akurat yang harus didukung informasi yang akurat, serta dikelola oleh staf yang sudah mahir menjalankan aplikasi dan paham dalam ilmu keuangan. Desa Kadacua cenderung minim menyediakan SDM yang siap menjadi pengelola teknis informasi dalam pengelolaa keuangan desa" (Wawancara, tanggal 23 Juni 2020).

BPKP (2016) menyatakan sistem keuangan desa berbasis komputer bersifat online yang muda dibaca publik. Oleh karena itu data yang diperlukan harus sesuai dengan format program yang dibuat sehigga tidak membingungkan masyarakat yang membacanya. Aplikasi 
sistem pengelolaan keuangan berbasis komputer dan secara online merupakan tuntutan ditengah perkembangan teknologi dan informasi. Penggunaan media elektronik bertujuan membantu pihak pengelola keuangan desa untuk dapat mengelola keuangan desa secara baik, efektif dan efisien, baik dalam hal penginputan pendapatan dan pengelolaan, pengolahan data yang terkait, pendistribusian, dan penyampaian laporan keuangan desa. Penyajian sistem informasi keuangan desa berbasis online memerlukan staf yang terampil dan memahami konsep pengelolaan keuangan desa. Persoalan SDM bukan semata jumlahnya yang banyak, dan kualitas atau kemampuan kerja yang tergambar dari pengetahuan dan keterampilan, tetapi selain itu, yang lebih penting adalah komitmen dan profesionalisme kerja dalam menyukseskan penerapan sistem keuangan desa.

Demikian pula, ketersediaan SDM bukan saja jumlahnya atau kesediaannya melainkan kontribsi pemikiran yang diberikan dalam menerapkan sistem keuangan desa menjadi penting. Di dua desa Kadacua dan Rombo Kecamatan Kulisusu Kabupaten Buton Utara, misalnya, kehadiran unsur terkait seperti Perangkat Desa, Lembaga setingkat Desa dan elemen masyarakat dan fasilitator Kecamatan yang memberikan kontribusi pemikiran dalam menyediakan komponen pendukung dengan mendukung langkah nyata untuk mewujudkan penerapan sistem keuangan desa. Termasuk dalam hal ini adalah kemampuan mengoperasional teknologi, kemampuan konseptual, kemampuan analitik, kemampuan kerjasama tim sebagaimana dikemukakan Supanji, dkk. (2017) ikut mendukung keberhasilan dalam kinerja pemerintah desa dalam menerapkan aplikasi sistem keuangan desa. Pada dua desa yang diteliti, masalah sumber daya manusia masih merupaan masalah yang menghambat penerapan aplikasi sistem informasi keuangan desa baik dari segi jumlah yang tersedia, maupun kualitas sumber daya manusianya sendiri. Kepala desa Kadacua Kecamatan Kulisusu mengemukakan bahwa:

"Ketersediaan SDM yang cukup dan berkualitas sangat kami harapkan dalam mendukung kinerja pemerintah desa dalam menerapkan aplikasi sistem keuangan desa, untuk saat ini kami sangat kekurangann yang hanya dibantu oleh fasilitator dan belum ada SDM sesuai kompetensi keilmuan yang berasal dari desa ini. Sementara untuk penerapan aplikasi sistem keuangan desa memerlukan operator yang faham tentang ilmu pengelolaan keuangan, dan mampu mengoprasikan komputer secara baik, yang saat ini kinerjanya belum maksimal" (Wawancara, tanggal 19 Juni 2020).

Penyajian data keuangan desa yang akurat merupakan adanya kinerja pemerintah desa dalam menerapkan aplikasi sistem keuangan desa yang efektif. Hal itu sejalan dengan Siregar (2016) dan Mardiasmo (2014) bahwa gambaran kinerja sistem keuangan desa yang akurat dapat dilihat pada setiap tahapan siklus penyelenggaraan keuangan desa mulai perencanaan, pelaksanaan, penatausahaan, pengawasan, pelaporan dan pertanggungjawaban, yang dalam penelitian ini ditemukan di dua desa yang diamati yaitu desa Kadacua dan desa Rombo Kecamatan Kulisusu Buton Utara belum berjalan dengan maksimal, meskipun masih dalam tahap ofline dengan penyajian sistem database keuangan desa, yang belum bisa diakses secara online. Hal yang sama juga diungkapkan Kepala Desa Rombo Kecamatan Kulisusu Kabupaten Buton Utara yang menjelaskan tentang dukungan sumber daya manusia yang kompeten selaku operator masih sangat terbatas jumlahnya, yaitu:

"Kami masih kurang dalam SDM baru satu yang siap, padahal idealnya, harus dua orang yang selalu siap ditempat, itu berarti minimal 2 orang operator, dengan melatih unsur aparat pemerintah desa. Untuk mengantisipasi kalau satu berhalangan masih ada yang siap menjalankan dan mengelola aplikasi siskeudes" (Wawancara, tanggal 22 Juni 2020). 
Dua desa yang diamati menjelaskan hal yang serupa, bahwa ketersediaan SDM masih sangat terbatas dan mereka memerlukan SDM yang kompeten untuk mendukung kinerja pemerintah desa dalam menerapkan aplikasi sistem keuangan desa. saat ini salah satu kendala yang dihadapi dalam proses penerapan aplikasi sistem keuangan desa secara berkesinambungan adalah sumber daya manusia yang kompeten dan terbatas. Ketersediaan SDM menurut pengalaman mereka sangat menentukan keberlangsungan kinerja pemerintah desa dalam menerapkan aplikasi sistem keuangan desa. Operator desa yang masih minim pengalaman dalam tatakelola keungan dimana besik keilmuan atau disiplin ilmu mereka tidak singkron, sehingga kinerja pemerintah desa dalam menerapkan aplikasi sistem keuangan desa belum berjalan secara maksimal.

Pembagian tugas tidak seimbang dan alokasi sumberdaya yang tidak proporsional, seringkali menjadi pemicu gagalnya. Hal ini diperkuat oleh penjelasan dari BPKP (2015) yaitu menjelaskan bahwa kinerja pemerintah desa dalam menerapkan aplikasi sistem Keuangan desa termasuk dalam proses pengelolaan keuangan desa adalah dukungan personil yang kompeten, Adanya personil yang siap mengelola sistem pelaporan keuangan desa berbasis online yang harus menguasai pengoperasian teknologi komputerisasi dalam sistem pelaporan keuangan desa (Amas, dkk, 2020).

Hal ini diperkuat oleh penjelasan dari BPKP (2015) yaitu menjelaskan bahwa kinerja pemerintah desa dalam menerapkan aplikasi sistem Keuangan desa termasuk dalam proses pengelolaan keuangan desa adalah dukungan personil yang kompeten, Adanya personil yang siap mengelola sistem pelaporan keuangan desa berbasis online yang harus menguasai pengoperasian teknologi komputerisasi dalam sistem pelaporan keuangan desa.

\section{SIMPULAN}

Berdasarkan hasil penelitian dan pembahasan kinerja pemerintah desa dalam menerapkan aplikasi sistem keuangan desa (Siskeudes) di kecamatan Kulisusu kabupaten Buton Utara, dengan melihat dimensi sistem kerja organisasi yaitu SDM yang kompeten dimana kinerja yang baik tergambar melalui tampilan output/hasil berupa data dan informasi yang cepat dan akurat sesuai harapan dalam penyajian data informasi keuangan desa yang didukung input memadai, proses yang baik, sehingga menghasilkan output maksimal. Dengan teknik analisis data yang digunakan adalah analisis kualitatif model interaktif, menunjukkan desa di kecamatan kulisusu SDM masih minim yakni output kinerja organisasi pemerintah desa belum berjalan maksimal dan efektif dalam hal sistem keuangan desa, dalam mendukung kinerja pemerintah desa dalam menerapkan aplikasi sistem keuangan desa di kecamatan Kulisusu kabupaten Buton Utara.

\section{REFERENSI}

Amas, Noor Wina. 2020. Efektivitas Aplikasi Sistem keuangan Desa Bagi Pemerintah Desa dalam Pelaporan Keuangan di Kabupaten Kolaka. Publica: Jurnal Administrasi Pembangunan dan Kebijakan Publik, Vol. 11 No. 2 Agustus, 232-242

Adisasmita dan Rahardjo, 2009, Pembangunan Pedesaan Dan Perkotaan. Yogyakarta: Graha Ilmu.

Ellitan, Leni dan Lina Anatan, 2009, Sistem Informasi Manajemen Konsep dan Praktis. Bandung: Alfabeta.

Gibson, James 1. Donnelly Jr, James H. Ivancevich, John M. Konopaske, dan Robert, 2012, Organizationa Behavior, Structure, Processes, Fourteenth Edition (International Edition).1221 Avenue of the Americas, New York, NY 10020: McGraw-Hill.

I Gusti Ayu Trisha Sulina, Made Arie Wahyuni, dan Putu Sukma Kurniawan, 2017, Peranan Sistem Keuangan Desa (Siskeudes) Terhadap Kinerja Pemerintah Desa (Studi Kasus Di Desa Kaba-Kaba, Kecamatan Kediri, Kabupaten Tabanan), E-Journal S1 
Ak Universitas Pendidikan Ganesha Jurusan Akuntansi Program S1 (Vol:8 No:2 Tahun 2017).

Jehan M. Malahika1, Herman Karamoy, dan Rudy J. Pusung. 2018. Penerapan Sistem Keuangan Desa (Siskeudes) Pada Organisasi Pemerintahan Desa (Studi Kasus Di Desa Suwaan Kecamatan Kalawat Kabupaten Minahasa Utara), Jurnal Riset Akuntansi Going Concern 13(4), 2018, 578-583.

Katz, Daniel Kahn, dan Robert 1. 2009. The social psychology of organizations.dalam becker \& neuhauser the efficient organizations. New York. Elsevier.

Komarudin. 2012. Manajemen Sumber Daya Manusia. Jakarta: Salemba Empat.

Mangkunegara dan Anwar Prabu. 2013. Manajemen Sumber Daya Manusia Perusahaan. Bandung: PT. Remaja Rosdakarya Offset.

Mardiasmo. 2016. Perpajakan . Edisi revisi tahun 2016. Yogyakarta: Penerbit Andi.

Puspawijaya, Adrian Nuritha, dan Julia Dwi Siregar. 2016. Pengelolaan Keuangan Desa; Pusat Pendidikan dan Pelatihan Pengawasan BPKP dalam rangka Diklat Teknis Substansi Pengelolaan Keuangan Daerah. Publikasi Edisi Kedua.

Patricia Watulingas, Lintje Kalangi, dan I Gede Suwetja, 2019, Peranan Sistem Keuangan Desa terhadap Kinerja Pemerintah Desa (Studi kasus di Desa Kapataran Kecamatan Lembean Timur Kabupaten Minahasa), Indonesia Accounting Journal (Volume 1, Number 2, Year 2019; 105-111).

Ratnaningsih, Indah Kadek dan I Gusti Ngurah Agung Suaryana, 2014, Pengaruh Kecanggihan Teknologi Informasi, Partisipasi Manajemen dan Pengetahuan Manajer Akutansi pada Efektivitas Sisem Informasi Akuntansi. ISSN: 2302-8556 EJurnal Akuntansi Universitas Udayana 6.1 (2014):1-16.

Sedarmayanti, 2011, Manajemen sumber daya manusia dan produktifitas kerja. Bandung: Reflika Aditama.

Salman dan Jumaili. 2015. Kepercayaan Terhadap Teknologi Sistem Informasi Baru Dalam Evaluasi Kinerja Individual. Simposium Nasional Akuntansi VIII. September: 722735.

Tangkilisan dan Hessel Nogis. 2009. Manajemen publik, Jakarta: Grasindo. 